Although it is often difficult to determine immediately the value for our future knowledge of physics of an investigation in pure science, this applies in still greater measure when we consider its significance for applied science or in the field of economics. Here things are not always so simple as in the discovery by E. Gumlich, who has worked in the Reichsanstalt since its foundation, that certain iron-silicon alloys have an extraordinarily small electrical conductivity and excellent magnetic properties. $\mathrm{He}$ immediately recognized the great importance of the diminution of eddy current losses, which depend on the conductivity, in sheet, used for the construction of transformers and dynamos. Gumlich's alloy sheet has found world-wide application, and it has been calculated that in Germany alone, by the use of the alloy sheet, industry saves in iron and electrical energy the equivalent of about one hundred million Reichsmarks a year.

Speaking generally, one can say that the statement made by Werner v. Siemens in 1884, in a memorandum urging the foundation of the Reichsanstalt, still holds good: "Almost without exception it is the result of new scientific discoveries, often with no apparent significance, that such new paths are opened up and important branches of industry newly created or revivified. Whether or not the recognition of a new scientific fact has a practical application cannot as a rule be determined until that fact has been systemati. cally and completely investigated, that is, often after an appreciable lapse of time. For this reason, scientific progress must not be made dependent on material interests."

The Reichsanstalt has never lost sight of this point of view, and its researches were never linked up only with considerations of time, for the high scientific value of its work of standardization is also bound up with its research work. In order to appreciate the spirit that has always been cultivated in the Reichsanstalt, it will suffice to mention the names of its presidents, in chronological order : H. v. Helmholtz, F. Kohlrausch, E. Warburg, W. Nernst, F. Paschen, and J. Stark. As already mentioned, the Reichsanstalt had not long been completed (in 1897) before great difficulties had to be faced as a result of the lack of accommodation and funds, and these reacted on its scientific development, in spite of the eminence of those in charge. Thus between 1897 and 1933 the effective area of its buildings increased only by about 35 per cent, mainly due to the construction of a heavy current laboratory (1913) and of a low-temperature laboratory (1927), and the funds available to the Reichsanstalt for its work lagged far behind those which would have corresponded to the enormous development of physics in the same period. But the new National. Socialist Minister Rust, who has been in office since 1933, began immediately to try to improve these conditions, and his Ministry has succeeded in aug. menting the available accommudation almost to double its earlier area, partly by renting suitable buildings, and partly by the acquisition of funds for the erection of new buildings, so that the number of Iaboratories of the Physikalisch-Technischen Reichsanstalt is now seventy-seven. This process of development is still being actively pursued, and Prof. Stark believes that the leaders of the National-Socialist State, recognizing the importance of the Reichsanstalt, will see to it that adequate financial aid is placed at its disposal, for without this the Reichsanstalt cannot fully realize its aims.

\title{
Apatite, Nepheline, and Rare-Earth Mining in the Kola Peninsula
}

$\mathrm{P}^{\mathrm{A}}$ ARTICIPANTS in the northern excursion of the seventeenth International Geological Congress in Russia were afforded ample facilities for inspecting recent mining developments in the Kola Peninsula, and especially the unique apatite deposits at Kirovsk. The latter occur within the world's largest known massif of nepheline-rocks, the Khibine Tundra*.

The Khibine massif (Umptek in the Loparian language) has an area of $1385 \mathrm{sq} . \mathrm{km}$. It is of roughly circular outline, with a diameter of about $40 \mathrm{~km}$. The neighbouring Lovozero massif to the east is similarly shaped, with diameter $25 \mathrm{~km}$. and

*The Lapp word tundra means the barren uplands above the limits of tree growth, and not the flat, frozen Arctic swamp lands; hence the Khibine and Lovozero Tundras as names applied to mountain groups. area 485 sq. $\mathrm{km}$. Still farther east there occur great intrusions of alkaline granites, which occupy an area of $3700 \mathrm{sq} . \mathrm{km}$.

The Khibine massif is of annular structure and may be regarded as a lopolith, with steep contacts cutting across Archæan gneisses and the Proterozoic Imandra-Varzuga series. A broad peripheral ring and the central area consist of coarsegrained nepheline-syenites. Along the annular break between these rings a series of younger fine-grained nepheline-syenites, and rocks of the ijolite-urtite range have been injected (see accom. panying map). The apatite-nepheline injections which are mined occur as intercalations within the ijolite-urtite series. 
The less well-known Lovozero Tundra (Lujavrurt) is also built of successive intrusions of the same types of rocks, but it appears to be a horizontally stratified sill-like mass. Both massifs abound in complex zirconotitanosilicate minerals, and minerals containing rare earths as well as niobium and tantalum. As xenoliths of hornfels with imprints of Devonian plants have been found enclosed within the nepheline-syenite of Lovozero, its age is certainly post-Devonian. Radium determinations have shown that the absolute age of the Khibine massif is about 350 million years. Hence Russian geologists assign both intrusions to the period of Variscian diastrophism.

The apatite-nepheline rocks that form the basis of the mining industry are confined to the hang. ing wall of the ijolite-urtite ring. The ore body is divided into an upper zone consisting of up to 80 per cent apatite and 20 per cent nepheline (average $\mathrm{P}_{2} \mathrm{O}_{5}$ content, 30.8 per cent), and a lower zone with predominant nepheline (4070 per cent), and $\mathrm{P}_{2} \mathrm{O}_{6}$ content ranging from 7 to 22 per cent.

The great new phosphate mine at Kirovsk, developed in eight years, is one of the industrial wonders of the world. This achievement is entirely due to Russian enterprise and energy. Owing to the close collaboration of seven organizations, the U.S.S.R. Academy of Sciences, the Arctic Institute, the Apatite Trust, the Scientific Institute of Fertilizers, the Central Geological and Prospecting Institute, the Rare Metals Trust, and the Leningrad Geological Trust, apatite is now being mined at the rate of 2 million tons per annum, and a reserve of 2,000 million tons has been established. The southern face of Kukisvumchorr Mountain has been blasted back into five broad ledges to a height of 1,500 feet. There are now more than twenty miles of underground galleries seven feet in height, electrically lit, and with electric haulage. A tunnel which admits the ordinary freight train has been driven to the heart of the mountain to facilitate loading. The social and industrial development of the region which, nine years ago, was a desolate arctic waste peopled by a few Lapp families, has kept pace with its scientific and technical investigation. The new town of Kirovsk with 40,000 inhabitants, and villages with the picturesque names of Nepheline and Apatite, have been built, and hundreds of miles of railway has been electrified.

Besides apatite, nepheline is mined for use in the ceramic industry and for its content of potash as fertilizer. The new mineral lovchorrite, a massive form of rincolite, chemically a fluorine-bearing titanosilicate of calcium, strontium and sodium, with up to 20 per cent of rare earths, is mined from pegmatites at the rate of several hundred tons a year. Another new mineral, loparite (titanoniobate of cerium, calcium and sodium) occurs in deposits of economic importance. Titanite (sphene)

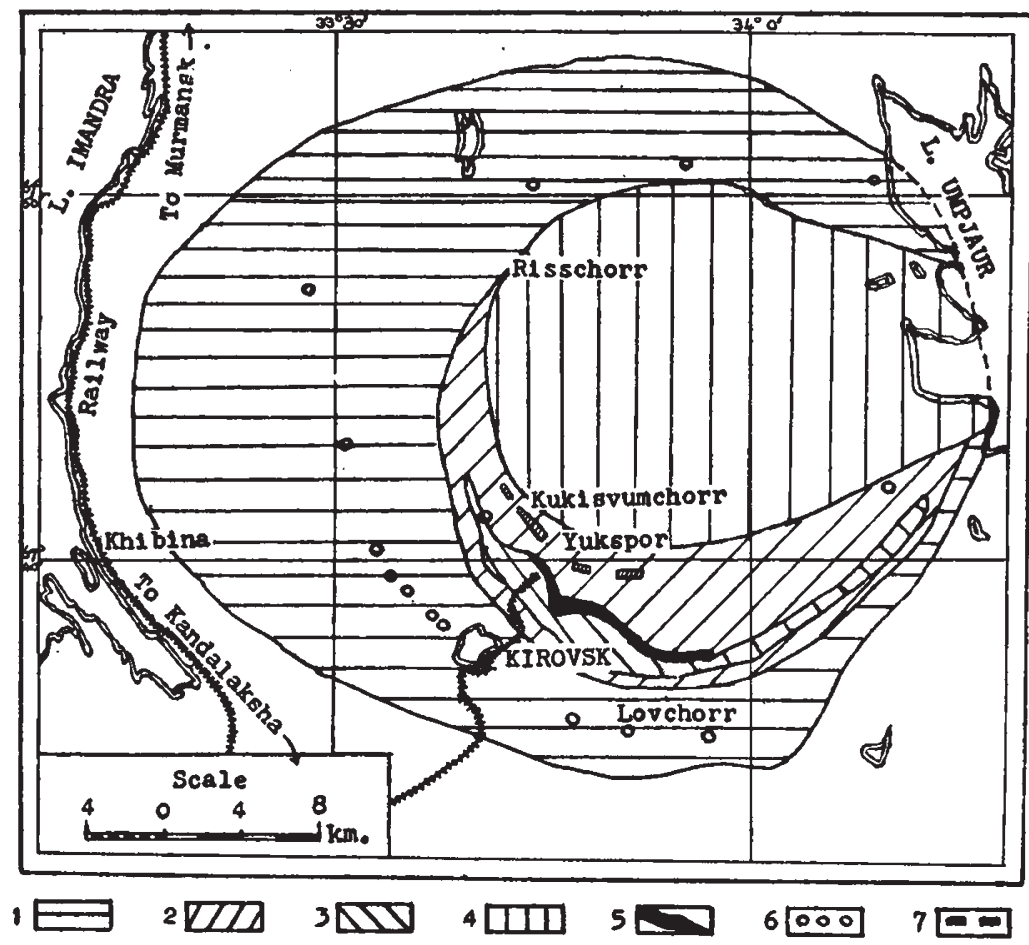

Geological Map of the Khibine Tundra, Kola Peninsula.

1, KHIBINITE (VERY COARSE-GRAINED NEPhELINE-SYENITE); 2, NEPHELINE-SYENITES (FINE-GRAINED TYPES); 3, IJOLITES AND URTITES ; 4, FoYAITE (COARSE-GRAINED NEPHELINE-SXENITE); 5, APATITE-NEPHEIINE ROCKS ; 6, OUTER ZONE OF RINCOLITE AND LOVCHORRITE DEPOSITS; 7, INNER ZONE OF RINCOLITE AND LOVCHORRITE DEPOSITS.

is also mined at the new Yukspor Mine, for what reason was not disclosed, but presumably for titanium, and possibly for its content of niobium and tantalum.

G. W. TYRRELL.

The chief sources of information are :

"Minerals of the Khibina and Lovozero Tundras" (English edition, abridged from the Russian monograph under the same title). U.S.S.R. Academy of Sciences, Moscow (see adv. in "Nature"); Memoir of the Lomonos80v Institute of the U.S.S.R. Academy of Sciences, 1937. Pp. 152. Edited by A. E. Fersmann. Offices of the 17th International Geology Congress, Bolshaya, Ordynka, 32, Moscow 17.

"The Northern Excursion, Kola Peninsula", Guide-book, XVIIth International Geological Congress, Moscow, 1937. Pp. 119. Edited by A. A. Polkanov. 